\title{
AFM を用いたナノインプリント金型用剥離剤の耐久性評価
}

\section{Durability assessment of the release agent for nanoimprint metallic molds using AFM}

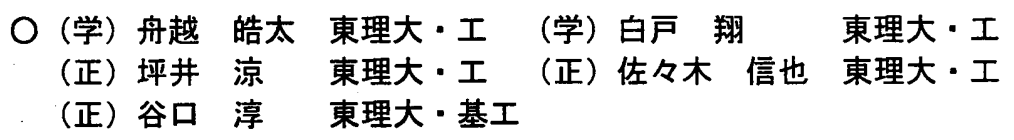

\begin{abstract}
Kouta Funakoshi, Tokyo University of Science, 1-14-6 Kudankita, Chiyoda-ku, Tokyo Shou Shirato, Graduate School of Tokyo University of Science, 1-14-6 Kudankita, Chiyoda-ku, Tokyo Ryo Tsuboi, Tokyo University of Science, 1-14-6 Kudankita, Chiyoda-ku, Tokyo Shinya Sasaki, Tokyo University of Science, 1-14-6 Kudankita, Chiyoda-ku, Tokyo Jun Taniguchi, Tokyo University of Science, 2641 Yamazaki, Noda, Chiba
\end{abstract}

\begin{abstract}
Ultraviolet-nanoimprint lithography (UV-NIL) is a powerful tool for mass production of nano-scale patterns. In UV-NIL, it is very important to coat the mold surface with a release agent to prevent the adhesion of UV curable resin. However, the release agent has a lifetime by repeated UV-NIL transfer. Therefore, release layer is degraded and UV curable resin adheres to the mold surface. In this study, to clarify the degradation of the release agent, the durability and friction properties are investigated. As the test specimens, base material is $\mathrm{Si}$ and release agents are Optool and F13. Hence, the tests are performed for Si, Si with Optool and Si with F13. The results showed that Optool is low friction force and Optool and F13 is maintained performance to 1000 times.
\end{abstract}

Key Words: Release agent, Dulability, nanoimprint, Optool, F13

\section{1. 緒言}

近年の IT 技術の進歩により，ネットワーク技術，ソフト ウェア技術およびデバイス技術のさらなる進展が必要とな っている.このため, 特に半導体デバイスの分野において は, 微細加工の高速化, 低消費電力動作, システムLSI とい う名で呼ばれる機能の統合化などの更なる発展が求められ ている. その半導体デバイスの生産プロセスのコアテクノ ロジーであるリソグラフィ技術は装置の微細化が進むにつ れ，装置価格の高騰化も同時に進んでおり問題となってい る. その問題の解決手段として,ナノインプリント技術が注 目を浴びている.

ナノインプリント技術は, ナノスケールの凹凸パターンを 形成した型（ナノモールド）を樹脂などに押し当て，樹脂の 表面にそのパターンを転写する加工技術である. 加工材料 は, 熱可塑性樹脂, UV (Ultraviolet) 樹脂, SOG（Spin on Glass）やガラス (1) などがある。いずれの材料においても， ナノモールドを被加工材料に押し当てることは変わりない が，被加工材料が固化する過程は異なる.ナノインプリント 技術の開発当初は, 熱可塑性樹脂を用いて, 冷却することで 固化を行う熱ナノインプリントリソグラフィが最も一般的 に用いられていた。しかしながら，レジストの昇温，冷却に かかる時間によるスループットの低下, 温度差による寸法変 化, 熱膨張による粗い面が生じることによる転写パターンの 精度の低下などの問題が生じた. そこで，これらを解決する ために, 熱以外の効果方法として, 開発された技術が光ナ， インプリントリソグラフィである. 光ナノインプリントリソ グラフィは, 被加工材料として UV 樹脂を用い, ナノモ一ル ドを押し当てている最中に紫外線を樹脂材料一照射して, 樹脂を硬化させる。これにより，熱による硬化に比べて，ス ループットが高く, 温度による寸法変化を防ぐことができる. また，紫外光を透過するモールドを使用するので，モールド を透過しての位置合わせを行えるという利点もある。このよ うな利点から, 光ナノインブリントリソグラフィは微細な 構造を簡便，かつ低コストに形成できるため，電子デバイ スをはじめ，バイオデバイスなどへの応用展開が期待され ている
しかしながら, もともと光硬化性樹脂は光ファイバーの接 着剂として使われており，付着性を有している，そのため， モールドを樹脂から剥離する際に，モールドと樹脂が付着し， 転写不良が発生するという問題がある。これは，ナノスケー ルにおいて顕著であり, 剥離時の付着面の摺動による凝着が 原因であると考えられる. そのため, 付着面の摩擦を減少さ せ, 樹脂の付着を減少させる性能を持つ光ナノインプリント イソグラフィに適した剥離剈の適用が求められている.

そこで, 本研究では, 光ナノインプリントリソグラフィに おける剥離剤の摩擦特性や耐久性などの性能評価を目的と して実験的検討を行った. 本報では，ピンオンディスク型往 復動摺動試験機および AFM（Atomic Force Microscope）を用 いて行った剥離剤の性能評価の結果を報告する.

\section{2. 実験条件}

本実験で使用した試験片は, オゾン洗浄のみを行ったシリ コン, Optool DSX (Daikin Co. ) (図 1) をコーティングした シリコン, F13 (図 2) (2) をコーティングしたシリコンの計 3 種類を用いた，各試験片の大きさは $20 \mathrm{~mm} \times 20 \mathrm{~mm}$ である.

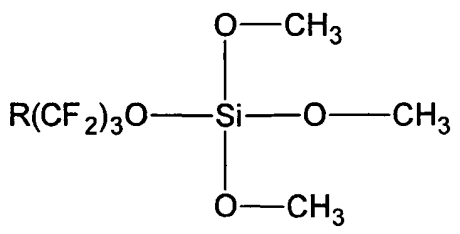

Fig. 1 Structural formula of Optool<smiles>FC(F)(F)CCCCCC(Cl)(Cl)C(F)(F)F</smiles>

Fig. 2 Structural formula of F13 


\section{3. 試験機}

ピンオンディスク型往復動摩擦試験機の概略を図3に示寸゙ ピンは先端にアクリル系のラジカル重合タイブの UV 硬化 樹脂（東洋合成工業,PAK-01）を塗布し，光硬化させたもの を使用し，5回摺動を行う毎に摩擦係数を測定した。試験条 件を表 1 に示寸。

Table 1 Test Condition of Tribotester
\begin{tabular}{|c|c|}
\hline Test method & Reciprocating \\
\hline Load, $\mathrm{N}$ & 20 \\
\hline Temperature, ${ }^{\circ} \mathrm{C}$ & 25 \\
\hline Speed, $\mathrm{mm} / \mathrm{s}$ & 5.0 \\
\hline Amplitude, $\mathrm{mm}$ & 10 \\
\hline Atmosphere & Air \\
\hline
\end{tabular}

AFM の概略を図 4 に示す。測定はコンタクトモードで行 い, 試験片の形状像を測定後,フリクショナルカーブを求め, 摩擦力を比較した。使用したカンチレバー（SN-AF01）は, $\mathrm{Si}_{3} \mathrm{~N}_{4}$ 製でチップ直径が $20 \mathrm{~nm}$ ，共振周波数が $34 \mathrm{kHz}$ ，バネ 定数が 0.08 であった。試験条件を表 2 に示す。

\begin{tabular}{|c|c|} 
Table 2 Test Condition of AFM \\
\begin{tabular}{|c|c|}
\hline Load, $\mathrm{nN}$ & 10 \\
\hline Temperature, ${ }^{\circ} \mathrm{C}$ & 25 \\
\hline Speed, $\mathrm{Hz}$ & 1.0 \\
\hline Amplitude, $\mu \mathrm{m}$ & 2.284 \\
\hline Atmosphere & Air \\
\hline
\end{tabular}
\end{tabular}

\section{3. 実験結果}

図 5 は往復動型摺動試験の結果である. 図 5 より, 剥離剂 をコーディングすることにより，摩擦係数は隇少することが 確認できた. Optool と F13 を比較すると Optool の方が摩擦
低減効果は良好な傾向を示した。また，Optool，F13 共に摺 動回数が 1000 回に達しても剥離した現象は見受けられな かった。

図 6 は AFMによるフリクショナルカーブである.フリク ショナルカーブの平均值は, $\mathrm{Si}$ が $0.246 \mathrm{~V}$, Optool が $0.0295 \mathrm{~V}$, F13 が $0.0646 \mathrm{~V}$ であった. 図 6 またフリクショナルカーブの 平均值から，コーディングすることにより，摩擦力が減少す ることは確認できた。 また Optool と F13 を比較すると摩擦 低減効果は Optool の方が良好な傾向を示し, 摩擦力の大き さは Optool が最も低い值となり，往復動型摺動試験時と同 様の傾向を得た。また往復動型摺動試験後に測定した形状像 を図 7 に示す。光硬化性樹脂の移着は，F13 において顕著に 見られた。

\section{4. 結言}

光ナノインプリントリソグラフィにおける剥離剈として Optool とF13 に着目し, 往復動摩擦試験機と AFM を用いて 性能評価を行い，以下の知見を得た。

(1) 剥離剂をコーティングすることで, 摩擦係数は減少する.

(2) Optool と F13 を比較すると, Optool の方が低い摩擦係数 の挙動を示した。

（3）摺動回数が 1000 回を超えても Optool と F13 は，共に剥 離せず剥離剤としての機能を維持した。

（4）光硬化性樹脂の移着は, F13 処理表面において顕著に見 られた

\section{引用文献}

(1) モノづくりのための実用材料の表面機能化設計テクノ ロジー, pp.709-713.

(2) D. Yamashita, J. Taniguchi, H. Suzuki, "Lifetime evaluation of release agent for ultraviolet nanoimprint lithography", Microelectronic Engineering, Vol. 97 (2012), pp.109-112.

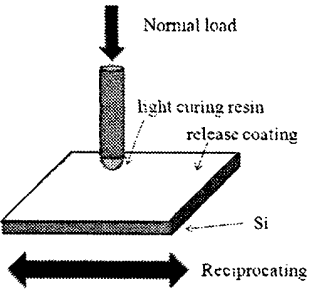

Fig. 3 Schematic of Tribotester Reciprocating cantilever

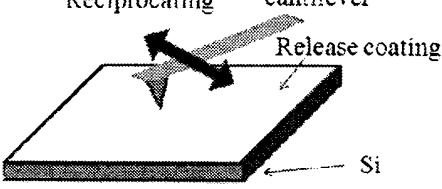

Fig. 4 Schematic of AFM

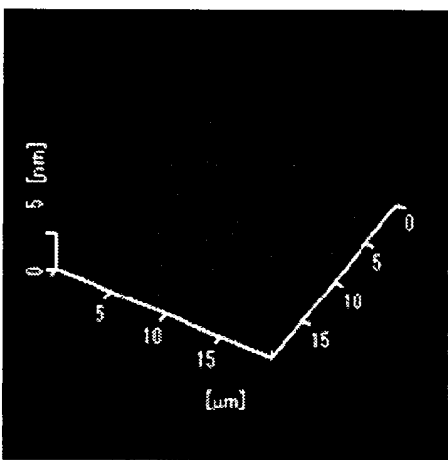

(a) $\mathrm{Si}$

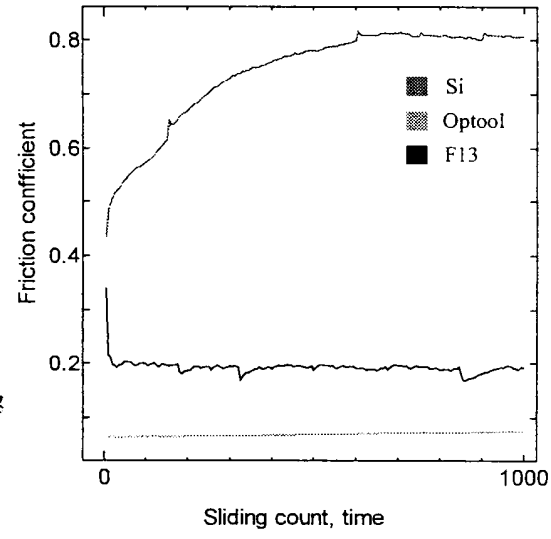

Fig. 5 Friction behavior in Tribotester

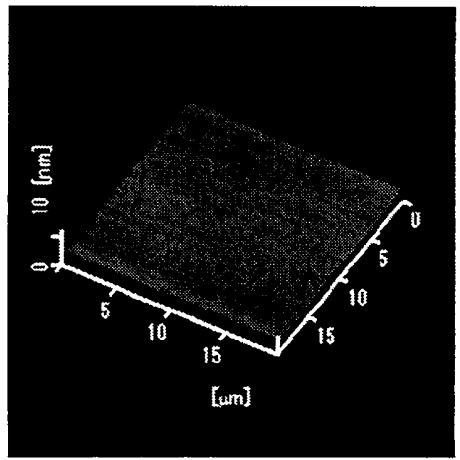

(b) Optool

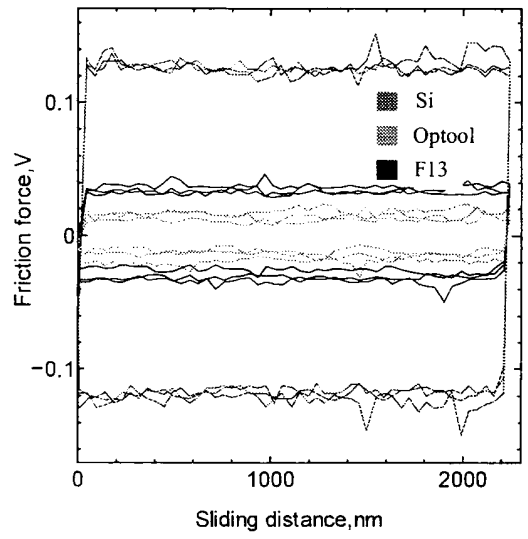

Fig. 6 Friction behavior in AFM

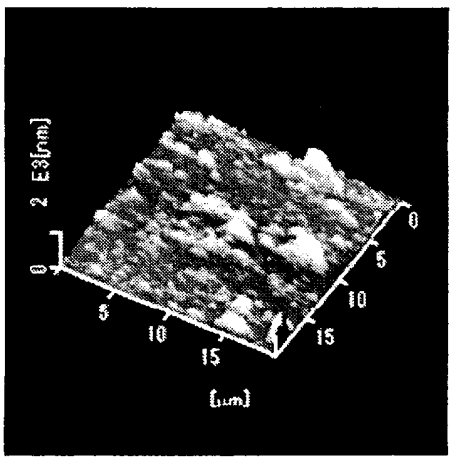

(c) F13

Fig. 7 Surface image of AFM (After Tribotester) 